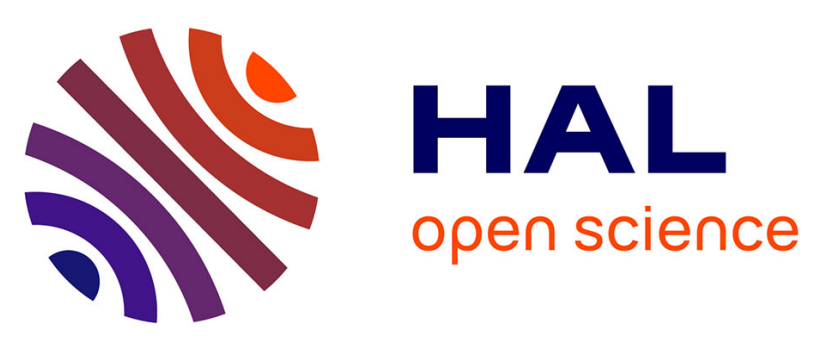

\title{
A novel POLH gene mutation in a xeroderma pigmentosum-V Tunisian patient: phenotype-genotype correlation.
}

Mariem Ben Rekaya, Olfa Messaoud, Amel Mebazaa, Olfa Riahi, Hela Azaiez, Rim Kefi, Mohamed Zghal, Samir Boubaker, Ahlem Amouri, Amel Ben Osman-Dhahri, et al.

\section{To cite this version:}

Mariem Ben Rekaya, Olfa Messaoud, Amel Mebazaa, Olfa Riahi, Hela Azaiez, et al.. A novel POLH gene mutation in a xeroderma pigmentosum-V Tunisian patient: phenotype-genotype correlation.. Journal of Genetics, 2011, 90 (3), pp.483-487. 10.1007/s12041-011-0101-y · pasteur-00859433

\section{HAL Id: pasteur-00859433 \\ https://hal-riip.archives-ouvertes.fr/pasteur-00859433}

Submitted on 8 Sep 2013

HAL is a multi-disciplinary open access archive for the deposit and dissemination of scientific research documents, whether they are published or not. The documents may come from teaching and research institutions in France or abroad, or from public or private research centers.
L'archive ouverte pluridisciplinaire HAL, est destinée au dépôt et à la diffusion de documents scientifiques de niveau recherche, publiés ou non, émanant des établissements d'enseignement et de recherche français ou étrangers, des laboratoires publics ou privés. 


\title{
A novel $P O L H$ gene mutation in a xeroderma pigmentosum-V Tunisian patient: phenotype-genotype correlation
}

\author{
MARIEM BEN REKAYA ${ }^{1}$, OLFA MESSAOUD ${ }^{1}$, AMEL MEBAZAA $^{3,4}$, OLFA RIAHI $^{3,4}$, HELA AZAIEZ $^{1}$, \\ RIM KEFI $^{1}$, MOHAMED ZGHAL ${ }^{5}$, SAMIR BOUBAKER ${ }^{2}$, AHLEM AMOURI ${ }^{1}$, AMEL BEN OSMAN-DHAHRI ${ }^{4}$, \\ SONIA ABDELHAK ${ }^{1 *}$ and MOURAD MOKNI ${ }^{3,4}$ \\ ${ }^{1}$ Molecular Investigation of Genetic Orphan Diseases Research Unit and ${ }^{2}$ Anatomo-Pathology Department, Pasteur \\ Institute of Tunis, 13 Place Pasteur, BP 74, 1002 Tunis Belvédère, Tunisia \\ ${ }^{3}$ Study of Hereditary Keratinization Disorders Research Unit and ${ }^{4}$ Dermatology Department, \\ La Rabta Hospital of Tunis, La Rabta, 1007 Tunis, Tunisia \\ ${ }^{5}$ Dermatology Department, Habib Thameur Hospital, 1008 Tunis, Tunisia
}

\begin{abstract}
[Ben Rekaya M., Messaoud O., Mebazaa A., Riahi O., Azaiez H., Kefi R., Zghal M., Boubaker S., Amouri A., Ben Osman-Dhahri A., Abdelhak S. and Mokni M. 2011 A novel POLH gene mutation in a xeroderma pigmentosum-V Tunisian patient: phenotype-genotype correlation. J. Genet. 90, 483-487]
\end{abstract}

\section{Introduction}

XP occurs at higher frequency in Tunisia $(1: 10,000)$ than in Japan (1:22,000) (Hirai et al. 2006) and the United States (1 per million) (Kleijer et al. 2008). XP-V cells are unable to synthesize intact daughter DNA strands on UV-irradiated templates resulting from an inability to carry out translesion synthesis (Lehmann et al. 1975; Masutani et al. 1999). Approximately $20 \%$ of XP patients belong to XP-V complementation group (Gratchev et al. 2003). In Tunisia, XP is classified into three clinical forms: severe, intermediate with or without neurological abnormalities, and moderate (Zghal et al. 2006). Previous molecular investigation showed homogeneity of mutational spectrum in XPA and XPC genes (Ben Rekaya et al. 2009; Messaoud et al. 2010a,b). The moderate clinical form of XP is characterized by mild dermatological manifestations, no neurological abnormalities and late onset of skin cancers. The median age of onset is 4 years. Mild skin symptoms and late onset of skin tumours have been already described in XP-V (Tanioka et al. 2007), XP-F (Matsumura et al. 1998) and XP-E patients (Rapić-Otrin et al. 2003). Post-UV cell survival in the presence or absence of caffeine (Itoh et al. 2000), unscheduled DNA synthesis (UDS) and detection of polymerase eta employing Western blot (Tanioka et al. 2007) cannot define exactly the molecular defects are in the polymerase eta. These laboratory assays are used to find out the UV sensitivities of the patients' cells and the DNA repair status of their cells as

*For correspondence. E-mail: sonia.abdelhak@pasteur.rns.tn. well as reduced levels or absence of expression of the protein predicts the defects in the polymerase eta. These parameters are very helpful in characterizing the XP patients' cells. The nucleotide sequencing confirms the defects in the XP genes. In the present study, we report the genetic and molecular analyses of $P O L H$ gene in a Tunisian patient with mild clinical phenotype suspected to be XP-V.

\section{Materials and methods}

The patient is a 75-year-old man who was hospitalized for an ulcerative tumour of the nose. He was born to consanguineous healthy parents and he originated from northwestern Tunisia. Family history revealed an XP affected brother and a paternal cousin who developed skin cancers after 55 years of age. The patient is a farmer by profession. He has no photophobia or ocular lesion. Although was often exposed to sunlight and had never used sunscreen, he did not sunburn easily. He developed two types of cancer separately: a pigmented basal cell carcinoma (BCC) of the left cheek at the age of 71; and a squamous cell carcinoma (SCC) of the labial commissural at the age of 72 (figure 1). Both were treated by surgery. On examination, the patient showed a poïkiloderma facial appearance with an ulcerative tumour on the left wing of the nose. Histological examination of skin biopsy showed a SCC. No ocular or neurological abnormalities were found. The patient had also hearing impairment and tooth decay. The hearing impairment is late onset according to the interview. No further audiometric test was possible.

Keywords. xeroderma pigmentosum-V; late-onset phenotype; novel mutation; phenotype-genotype correlation. 


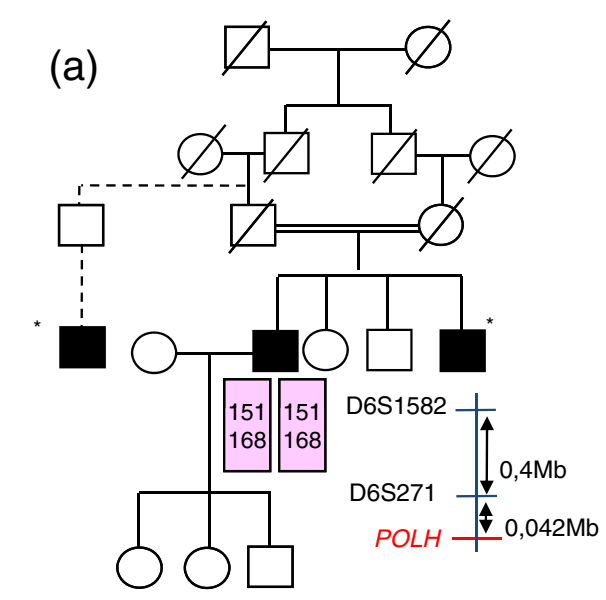

*According to the family history (b)
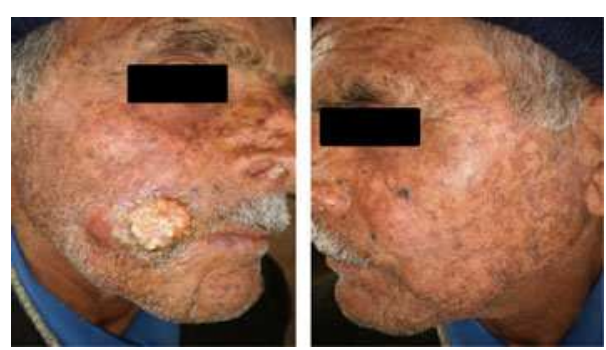

(c)

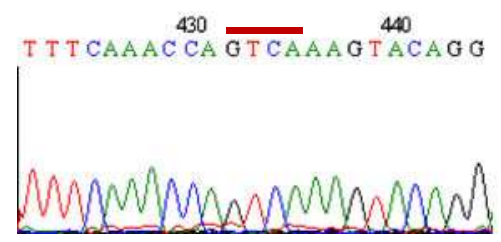

Wild type

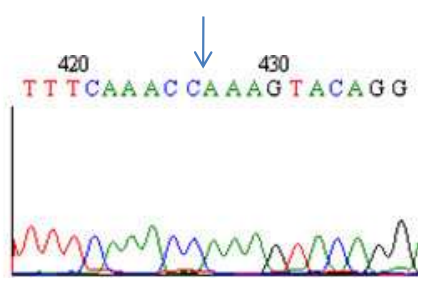

p.S523KfsLX16

Figure 1. (a) The pedigree of the multiplex XP-V family and haplotype analysis with microsatellite markers close to the $P O L H$ gene. (b) Clinical photos of the affected patient, showing a poikiloderma facial and a SCC tumour lesion. (c) The sequence electropherogram of the sense strand in exon 11 showing the GTCA deletion which leads to the S523KfsLX16 mutation in comparison with the wildtype sequence of an unrelated control.

After obtaining patient's informed consent, genomic DNA was extracted from whole peripheral blood by salting out method. Linkage to $P O L H$ gene was performed using two informative microsatellite markers spanning a $0.4 \mathrm{Mb}$ interval near to POLH locus (cen-D6S1582, D6S271, $(P O L H)$ tel) (figure 1). Mutations were screened by direct sequencing of exons 10 and 11 of $P O L H$ gene.

\section{Results and discussion}

The patient developed his first skin cancer at the age of 71 years. This age is over the average age of onset of skin cancer in XP-V patients, estimated at 45 years (Johnson et al. 1999; Masutani et al. 1999; Itoh et al. 2000; Broughton et al. 2002; Tanioka et al. 2007; Inui et al. 2008; Masaki et al. 2008) and it is even higher than the average age of skin cancers in the general Tunisian population (55 years) (Mseddi et al. 2007). Hearing abnormalities were not previously described in XP-V patients; this particular association observed in the reported case may be due to his old age (presbycusis). Genetic study showed that the patient had a homozygous haplotype (151-168) for markers D6S271 and D6S1582 suggesting linkage to the $P O L H$ gene (figure 1). We first screened exon 10 where a previous mutation in a Tunisian XP-V patient was described (Broughton et al. 2002) but no mutation was identified. Considering similar genetic background with the Algerian population, we screened exon 11 in which a mutation has been reported in an Algerian patient (Broughton et al. 2002). Sequencing of this exon revealed a novel deletion of four bases in homozygous state c.1568_1571delGTCA (figure 1). This small deletion likely leads to a truncated protein; p.S523KfsX16, containing an intact polymerase activity domain located in the first 511 amino acids (Masutani et al. 1999) but lacking the terminal nuclear localization signal (C-NLS) situated between amino acids 682698 and the PCNA (proliferating cell nuclear antigen) binding site located between amino acids 707 and 708 (Yang and Woodgate 2007). This suggests that the mutation found in our patient does not reduce the polymerase activity explaining his mild phenotype. Many mutations in the POLH gene have been described in Chinese, American, European and Japanese XP-V patients. Most of them lead to truncated proteins (Masutani et al. 1999; Tanioka et al. 2007; Itoh et al. 2000; Johnson et al. 1999; Broughton et al. 2002; Inui et al. 2008; Masaki et al. 2008). Only $10 \%$ of reported mutations are located in exon 11 although it corresponds to $42 \%$ of the coding region (table 1). This low number of mutations observed in this exon may be due to the under diagnosis of moderate clinical forms (Gratchev et al. 2003). No correlation between clinical features and the different POLH mutations has been found among previous XP-V reported cases (Tanioka et al. 2007; Inui et al. 2008). Generally, assessment of phenotype-genotype correlation in patients with XP is complicated because the clinical features are correlated with the degree of exposure to sunlight which is related among others to patient's age. We have previously described a complete phenotype-genotype correlation among Tunisian XP-A and XP-C patients (Ben Rekaya et al. 2009; Messaoud et al. 2010a,b). To investigate a possible phenotype-genotype correlation we reviewed all XP-V patients reported in the literature who had a mutation in 


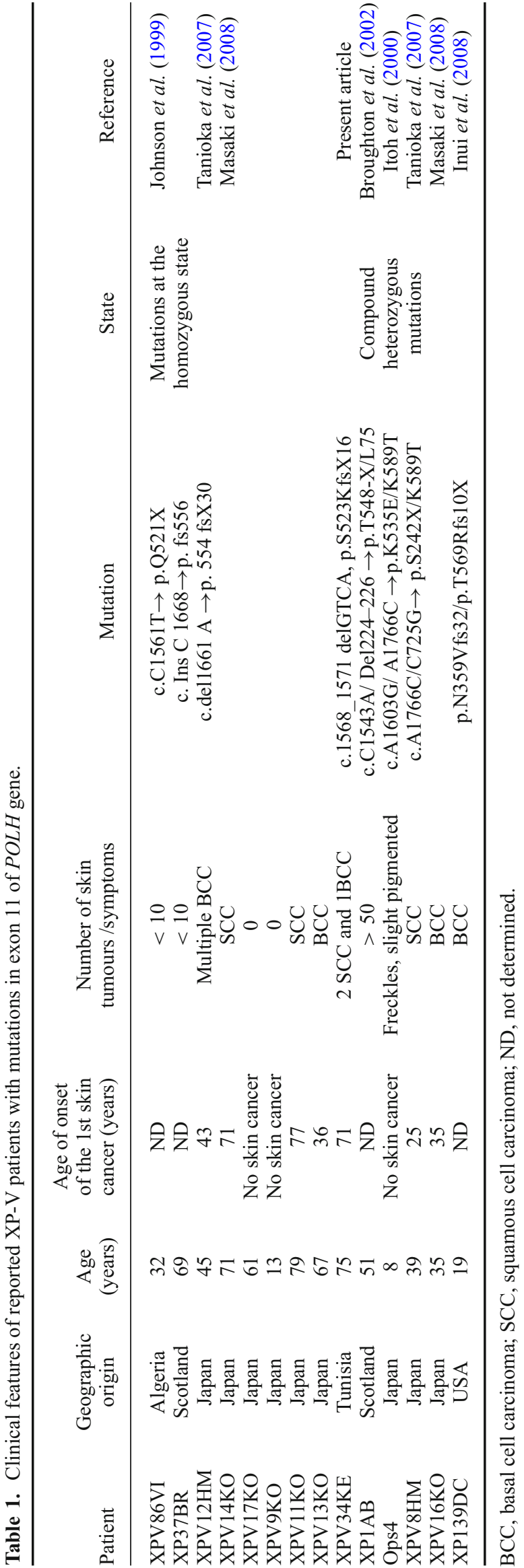

exon 11 (table 1) (Itoh et al. 2000; Broughton et al. 2002; Tanioka et al. 2007; Inui et al. 2008; Masaki et al. 2008). Nine patients had mutation at homozygous state in exon 11, while the other five were heterozygous with one mutation in exon 11 and the second located elsewhere. Among the nine homozygous patients three (XPV14KO, XPV11KO and XPV34KE) developed their first skin cancer after the age of 71 years and one 61-years-old patient (XPV17KO) did not have any cancer. In contrast, among the five compound heterozygous patients, two (XPV8HM and XPV16KO) developed their first skin cancer at the age of 25 and 35 years respectively; one patient XP1AB (51 years old) developed more than 50 skin cancers and the patient XP139DC had $\mathrm{BCC}$ at 19 years. For Ops4, who has two mis-sense mutations in the catalytic domain, as he was 8 years old, he is too young to develop skin cancers (table 1). It seems that patients having a mutation at the homozygous state in exon 11 shared a milder phenotype than patients being compound heterozygous (only one allele mutated in exon 11 and the other affecting upstream of exon 11 thus likely affecting the catalytic domain) (figure 2). A previous study revealed that healthy individuals who are heterozygous for $P O L H$ mutation showed reduced levels of recovery of replicative DNA synthesis in the presence of caffeine after UV irradiation (Itoh et al. 2000). A phenotype-genotype correlation could be established in XP-V patients when a distinction is made between homozygous and compound heterozygous patients. Based on all cases published analysis, we hypothesize that mutations outside the catalytic domain of pol eta is always associated with a very mild phenotype regardless of the type of mutation. Generally many factors might be related to the development of skin cancers such as the localization of the mutation, accumulation of sun exposure, lifestyle of a patient and other genetic determinants like protective polymorphisms (Masaki et al. 2008).

Taking into account the geographic and demographic features in Tunisia, i.e a sunny weather exposing to UV radiation and the high rate of endogamy that contributes to an increase in genetic diseases, it would be of great interest to perform mutation screening of $P O L H$ gene in patients showing photosensitivity in an effort to prevent skin cancer.

\section{Acknowledgements}

We would like to thank the patient as well as the patients' support group 'Aide aux enfants atteints de Xeroderma Pigmentosum' (http://www.xptunisie.org.tn) for their collaboration. This work was supported by the Tunisian Ministry of Higher Education and Scientific Research (Research Unit on 'Molecular Investigation of Genetic Orphan Diseases' UR 04/SP03) and the Tunisian Ministry of Public Health.

\section{References}

Ben Rekaya M., Messaoud O., Talmoudi F., Nouira S., Ouragini H., Amouri A. et al. 2009 High frequency of the V548A fs X572 


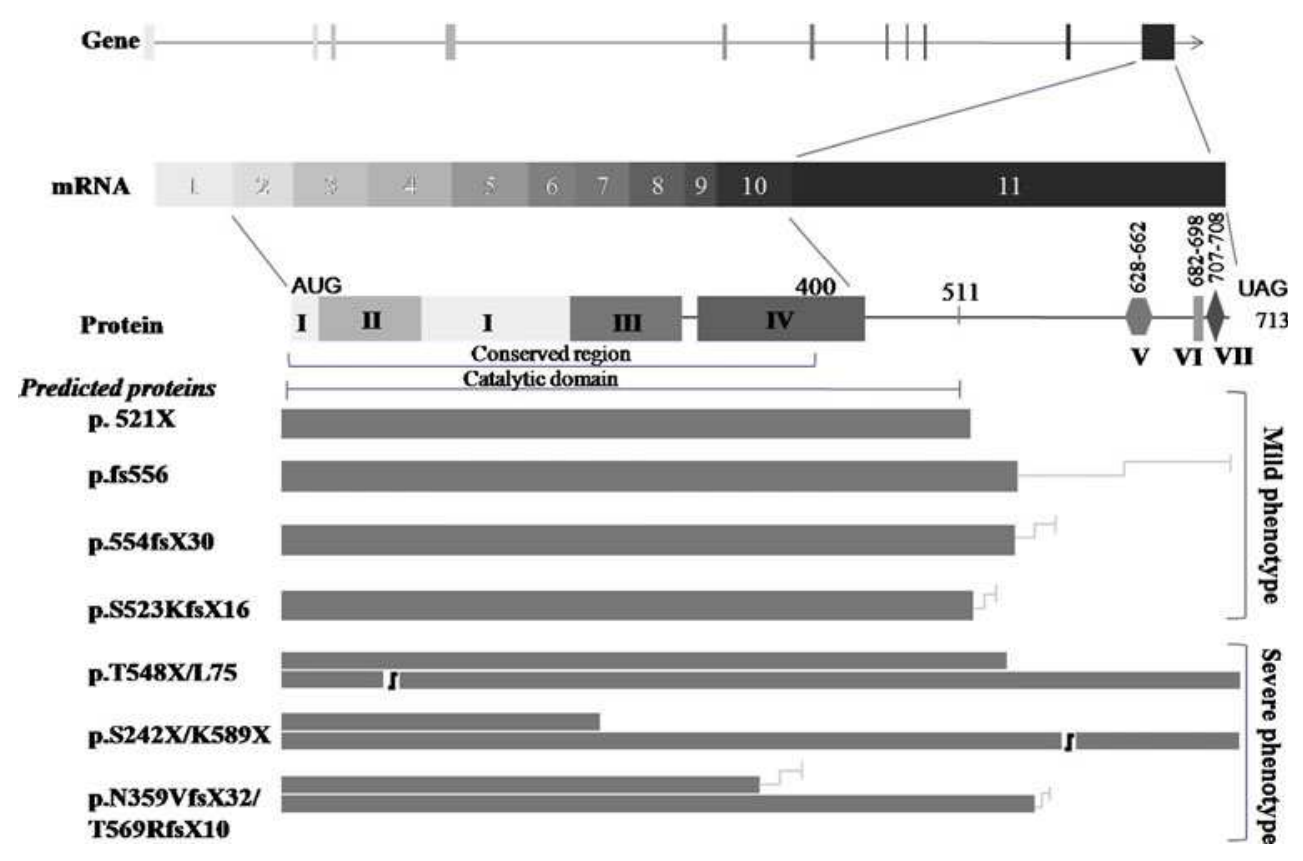

Figure 2. Mutation spectrum in exon 11 of $P O L H$ gene and predicted proteins in XP-V cells. The top line shows the 11 exons of $P O L H$ gene. The second line shows mRNA with the ATG initiation codon in exon 2 and the TAG stop codon in exon 11 . The 713 amino-acid pol $\eta$ protein is shown in the third line: the 400 amino acid $\mathrm{N}$ terminal domain is highly conserved in Y-family polymerases and contains the catalytic domain of the polymerase: The polymerase domain I (palm), II (finger), III (thumb), IV (LF, little finger). The C-terminal region from amino acids 628-662 (UBZ, domain V) contains a C2H2 zinc finger that is involved in DNA-binding ubiquitin. There is a nuclear localization signal (NLS, domain VI) located at amino acids 682-698. A PCNA, binding site (B/PIP, domain VII) is located at the extreme $\mathrm{C}$ terminus of the protein (707-708). The bottom portion of the figure shows the different predicted protein sizes associated to each allele described in the reviewed XP-V patients. UBZ, ubiquitin binding zing domain; NLS, nuclear localization signal; B/PIP, $\beta$ clamp/ PCNA interacting peptide; NLS, nuclear localization signal; B/PIP, $\beta$ clamp/ PCNA interacting peptide.

XPC mutation in Tunisia: implication for molecular diagnosis. J. Hum. Genet. 54, 426-429.

Broughton B. C., Cordonnier A., Kleijer W. J., Jaspers N. G., Fawcett H., Raams A. et al. 2002 Molecular analysis of mutations in DNA polymerase eta in xeroderma pigmentosum-variant patients. Proc. Natl. Acad. Sci. USA 99, 815-820.

Gratchev A., Strein P., Utikal J. and Sergij G. 2003 Molecular genetics of xeroderma pigmentosum variant. Exp. Dermatol. 12, $529-536$.

Hirai Y., Kodama Y., Moriwaki S., Noda A., Cullings H. M., Macphee D. G. et al. 2006 Heterozygous individuals bearing a founder mutation in the XPA DNA repair gene comprise nearly $1 \%$ of the Japanese population. Mutat. Res. 601, 171-178.

Inui H., Oh K. S., Nadem C., Ueda T., Khan S. G., Metin A. et al. 2008 Xeroderma pigmentosum-variant patients from America, Europe, and Asia. J. Invest. Dermatol. 128, 2055-2068.

Itoh T., Linn S., Kamide R., Tokushige H., Katori N., Hosaka Y. and Yamaizumi M. 2000 Xeroderma pigmentosum variant heterozygotes show reduced levels of recovery of replicative DNA synthesis in the presence of caffeine after ultraviolet irradiation. J. Invest. Dermatol. 115, 981-985.

Johnson R. E., Kondratick C. M., Prakash S. and Prakash L. 1999 hRAD30 mutations in the variant form of xeroderma pigmentosum. Science 285, 263-265.

Kleijer W. J., Laugel V., Berneburg M., Nardo T., Fawcett H. and Gratchev A. 2008 Incidence of DNA repair deficiency disorders in western Europe: xeroderma pigmentosum, cockayne syndrome and trichothiodystrophy. DNA Repair 7, 744-750.

Lehmann A. R., Kirk-Bell S., Arlett C. F., Paterson M. C., Lohman P. H., de Weerd-Kastelein E. A. and Bootsma D. 1975 Xeroderma pigmentosum cells with normal levels of excision repair have a defect in DNA synthesis after UV-irradiation. Proc. Natl. Acad. Sci. USA 72, 219-223.

Masaki T., Ono R., Tanioka M., Funasaka Y., Nagano T., Moriwaki S. and Nishigori C. 2008 Four types of possible founder mutations are responsible for $87 \%$ of Japanese patients with Xeroderma pigmentosum variant type. J. Dermatol. Sci. 52 , 144-148.

Masutani C., Kusumoto R., Yamada A., Dohmae N., Yokoi M. and Yuasa M. 1999 The XPV (xeroderma pigmentosum variant) gene encodes human DNA polymerase eta. Nature 399, 700-704.

Matsumura Y., Nishigori C., Yagi T., Imamura S. and Takeke H. 1998 Characterization of molecular defects in xeroderma pigmentosum group $\mathrm{F}$ in relation to its clinically mild symptoms. Hum. Mol. Genet. 7, 969-974.

Messaoud O., Ben Rekaya M., Cherif W., Talmoudi F., Boussen H., Mokhtar I., Boubaker S., Amouri A., Abdelhak S. and Zghal M. 2010a Genetic homogeneity of mutational spectrum of group-A xeroderma pigmentosum in Tunisian patients. Int. J. Dermatol. 49, 544-548.

Messaoud O., Ben Rekaya M., Kefi R., Chebel S., BoughammouraBouatay A., Bel Hadj Ali H., Gouider-Khouja N., Zili J., FrihAyed M., Mokhtar I., Abdelhak S. and Zghal M. 2010b Identification of a primarily neurological phenotypic expression of xeroderma pigmentosum complementation group A in a Tunisian family. Br. J. Dermatol. 162, 883-886.

Mseddi M., Marrekchi S., Abdelmaksoud W., Bouassida S., Meziou T. J., Boudaya S., Masmoudi A., Zahaf A. and Turki H. 2007 Epidemio-clinical profile of skin cancer in southern Tunisia. Tunis. Med. 85, 505-508. 
Rapić-Otrin V., Navazza V., Nardo T. and Botta E. 2003 True XP group E patients have a defective UV-damaged DNA binding protein complex and mutations in DDB2 which reveal the functional domains of its p48 product. Hum. Mol. Genet. 12, $1507-1522$.

Tanioka M., Masaki T., Ono R., Nagano T., Otoshi-Honda E. and Matsumura Y. 2007 Molecular analysis of DNA polymerase eta gene in Japanese patients diagnosed as xeroderma pigmentosum variant type. J. Invest. Dermatol. 127, 1745-1751.

Yang W. and Woodgate R. 2007 What a difference a decade makes: insights into translesion DNA synthesis. Proc. Natl. Acad. Sci. USA 104, 15591-15598.

Zghal M., Fazaa B. and Kamoun M.-R. 2006 Xeroderma pigmentosum. EMC (Elsevier SAS, Paris) Dermatologie 10, 98-660.

Received 2 March 2011, in final revised form 25 May 2011; accepted 14 June 2011

Published on the Web: 14 November 2011 